\title{
Explicit Instruction In Unisono Singing Lessons in Class VII Public Junior High School (Sekolah Menengah Pertama-SMPN) 1 Padang Panjang
}

\author{
$1^{\text {st }}$ Syeilendra* \\ FBS, Padang State University \\ syeleindrasendratasik@gmail.com
}

\author{
$2^{\text {nd }}$ Budiwirman \\ FBS, Padang State University
}

\begin{abstract}
This research aims to determine the difference in the outcome of singing Unisons sing students given the method of learning explicit instruction rather than conventional methods. Interaction between explicit instruction methods with conventional method of learning result of Unisons singing. The results showed that overall, through advanced testing proved that the result of learning Unisons singing students who are given a method of learning explicit instruc-
\end{abstract}

\section{INTRODUCTION}

Learning is a process and activity carried out by one to produce a change of attitudes and behavior that is new thoroughly private. The learning process is as a result of his own experience in interaction with his environment. Learning can also be interpreted as a process by which behavior is changed through exercises or personal experiences that are able to alter the previous behavior that educators can do to participants in the classroom. As a change of behaviour to such individuals is due to the interaction between individuals and individuals, and individuals with the environment. This change in behaviour involves a change of knowledge, attitude, and skill.

Learning is a process that must be created for a teacher or a teacher to achieve a learning objective in accordance with the reference of the standards of the planned core competencies, which are listed in the implementation of eye learning Subjects. The Learning plan must be prepared by a teacher or lecturer before the learning process is completed with learning. tion is higher than the learning results of the Unisons singing students who are given Learning treatment with conventional methods. From research shows that the outcome of learning to sing Unisons students on both treatments gives a significant difference.

Keywords-Explicit Instruction, Singing Unisono

For subjects related to theoretical and skill materials, a teacher has really prepared all the needs in the classroom for a walking learning activity that is already referring to learning objectives. Nevertheless, without realizing it can be a problem can occur during the learning process. For example, the problems in the classroom are not conducive, caused by the time of study was noon due to the number of subjects from the first hour to the daytime hours students are overwhelmed by the various assignments and teaching materials of other subjects. So at noon hours this is often the atmosphere of the class is less conducive.

The results of early observation of researchers in class VII SMPN 1 Padang Panjang in the subjects of cultural arts that time to study was not very serious. The above issues often arise resulting in teachers becoming overwhelmed with students for further learning activities. The observed observation is the music material associated with a unisono singing. Unisono singing is a unique way of organizing and creating a sense of voice/vocals for individual learners. In singing will express the voice/music, emotion, intellectual, and imagination manifested through sound. 
The singing of Unisono is in the form of a sound like reading the melody notation of a song (a scores of songs that are just the core melody). Benyanyi Unisono cannot be executed by a self but must be done in the classical one vote. Benyanyi Unisono time is required to cooperate and be sensitive and understand each other so that the sound is good. Singing Unisono is one of the techniques in singing that must be mastered in learning singing in the VII class that suits the cultural art curriculum. In order to sing Unisono, students are required to complete both in their knowledge and practical skills. However, in fact, students of class VII SMPN 1 Padang Panjang are still found the achievement of the minimum criteria value that has been set by the standard value is 75 .

During the observation, researchers found some issues related to the Unisono singing in class VII SMPN 1 Padang Panjang. In the skill and knowledge of Unisono singing that is owned by the students is still very minimal, seen from students who have been struggling during the practice of practicing unisono singing lessons. Many of the students still don't understand how basic techniques in singing are good, such as unclear articulation, improper phrasering, and improper intonation. In fact, these three are one of the basics in singing techniques that students should understand. When teachers ask questions and ask students to use the song scores, the tone produced by the students while singing Unisono is still discordant. Seen in adjusting the color of the sound of students still difficult and do not understand how to do. Similarly, breathing techniques that students do when singing is not precise and different, then in the practice of singing a body attitude that students do not precisely. The serious consequences of time practicing students look unconfident and embarrassed to produce a sound when singing Unisono.

In delivering teaching materials, educators/ teachers in carrying out the learning process using the lecture methods and dictated the teaching materials and students are recorded in the notebook. Teachers are more dominant in communicating unisono singing learning materials rather than practicing. Theories in the Unisono singing learning teachers give to make students in the classroom saturated and passive when they follow the lesson. Thus, it causes the learning process given by the teacher to focus on the theory of learning. The art of culture, especially this unisono singing, teachers must be balanced in conveying both the lesson materials and practice. Sometimes teachers provide teaching materials through a copy of a photocopy written by the teacher as a reading material for the students as well as a copy of the song material taken from the Cultural art package book. At the time of closing the students are given assignments in the home that is to move and repeat from the results of the photos copy given by the teacher.

The method used by the teacher is good enough to convey learning, but the ability to innovate on the methods that teachers do in learning Unisono singing, making the learning process does not work properly that has been designed In the implementation of previous studies. This leads to a lot of students who are not interested and lazy to pay attention to the teacher while describing the learning about Unisono.

When students have been bored and saturated, some students are looking for other activities outside of the ongoing learning process. Like, doing other tasks in the hour of cultural art learning process, then there are students who make other student concentrations disturbed, unisex students who often go out of class, and there are also students who make noise that will lead to The learning process will not run properly, and students are not able to receive lessons well.

Addressing the problems that occur in the class teachers must find the solution, so that the learning problems in the class are not repeated. So the creative thought has been raised. Because creative thinking is one of the avenues to open a new atmosphere in inviting learners to do. The creative cause will appear when a desire that urges one's soul to create something new can make the learners eager to follow the learning earnestly. With the effectiveness of such creativity that is associated with the teaching material, in itself, the learning certainly goes according to the purpose of 
learning that will yield maximum learning out comes.

There fore, the teachers must be able to find solutions to make learning properly in the form of creative, innovative, effective learning that is interesting by using various learning tools. Through the learning model is expected to improve the results of singing learning in Unisono. To anticipate Unisono singing learning problems will use explicit instruction model for Unisono singing problems answered. Students are expected to develop their ideas and ideas in order to increase knowledge and to improve the results of the study of singing in the VII class at SMPN 1 Padang Panjang.

The explicit instruction learning Model is implemented to develop the learning process about procedural knowledge and declarative knowledge with the learning process using pattern step by step. [2) describes that the model explicit instruction known as direct instruction is one of the teaching approaches that are planned specifically to support the implementation of the learning process of students related to Structured procedural knowledge that can be implemented through gradual activity patterns, and in a systematic level.

The direct instruction Model is a teaching approach that is able to help students learn basic skills and know the information that can be used in step-by-step learning. The learning process is often called a direct teaching model (Kardi and Nur, 2000:2). [2] further describe the same thing that :"A teaching model that is aimed at helping student learns basic skills and knowledge that can be taught in a step-by-step fashion. For our purposes here, the model is labeled the direct instruction model". Educators in using this direct teaching model, must have a sense of responsibility to identify from learning objectives and are responsible for the delivery of teaching materials or materials or skills, to describe to students, demonstrate that combined in the form of practice and give students the opportunity to be more vigorous in practicing and use the concepts and Skills already learned and able to give conclusions from learning. A direct teaching Model designed specifically to support the implementation of learning, so that all students who relate to the procedural knowledge and declarative knowledge are properly structured, which can be taught through With a gradual, step-by-step activity pattern. The above problem was also conveyed by [2] that: "The direct instruction model was specifically designed to promote student learning of procedural knowledge and declarative knowledge that is well structured and can be taught in a step-by-step fashion."

Based on the aforementioned further [2] described as follows:

Direct instruction is a teacher-centered model that has five steps: establishing set, explanation and/or demonstration, guided practice, feedback, and extended practice A direct instruction lesson requires careful orchestration by the teacher and a learning environment that businesslike and taskoriented.

The same issue was also reinforced by Kardi and Nur (2000a: 27), stating that a lesson with a direct learning model went through five steps: (1) A description of students' objectives and readiness, (2) The mastery of teaching materials that will be taught Through demonstrations of special skills, (3) Directing guided exercises, (4) controlling and providing feedback, and (5) guiding self-training.

Explicit instruction learning can be interpreted as a teaching approach that is deliberately designed to improve the learning process for the students to be maximal. The Convention learning process relates to declarative and systematic procedural knowledge that can be taught in a gradual way that is step-by-step often referred to as a learning model Direct.

Explicit instruction learning can be interpreted as a teaching approach that is deliberately designed to improve the learning process for the students to be maximal. The Convention learning process relates to declarative and systematic procedural knowledge that can be taught in a gradual way that is step-by-step often referred to as a learning model Direct.

Explicit Instruction, Quoted by Kardi (in Huda, 2013:186), learning can be in the form of "lectures, demonstrations, training or practice, 
and group work". Meanwhile, according to Majid (2013:72-73) explains that: direct learning is generally made specifically in order to develop student learning activities related to aspects of procedural knowledge of how to implement A declaratory knowledge related to the knowledge of something that can be a fact, concept, principle, or generalization that is well-guided and can be learned step by step. As a primary focus of this learning is the trainings that can be applied from simple real-life circumstances to a more complex one. Then explicit intruction learning can be a learning approach that is deliberately designed to develop students' learning about the procedure knowledge and declarative knowledge that the teacher can teach in step-by- Step.

Based on the explanation above it can be concluded that explicit intruction is a direct learning model that aims to allow students to understand and truly know the knowledge thoroughly and actively in a Learning. By implementing the method of explicit instruction in the process of implementing cultural art learning will be able to tackle learning issues related to teaching materials that include pratikum material.

\section{METHOD}

The method used in this research is the experimental method. This method is validation or test (Krathwohl 1997, H.7), which is to test the influence of one or more variables of another variable. The type of experiment used is quasi experimental design (pseudo experiments). In this experimental study, consisted of two classes, namely the control class and the experimental class. In the initial stage, the control class and the experiment class will be pre-test To know the level of students' understanding of the Unisono singing. Then, the experiment class will be given a specific treatment or stimulus according to the steps of the learning model explicit instruction, While in the control class will run as usual. In class-end activities, the control and experiment classes are given post-test.

This type of research is an experiment by dividing learners into two learning groups: an experimental class with a control class. The experimental class with Unisons singing learning materials uses the explicit instruction model. As for the control class with the same material using conventional learning methods.

The types of research used are quantitative research types. [10] explains that quantitative research is a study used to research on certain populations or samples. While the instrument to be used in this research is in the form of tests, namely tests to measure the ability of singing Unisono learners. Before the instrument is used for data retrieval, the instruments are tested first. It is done to know the validity and reliability of the instrument and to test its validity and to calculate its reliability.

The population is a grade VII student at SMPN 1 Padang Panjang 6, amounting to 150 students. The population technique used in determining the experimental class and the control class is simple random sampling.

The research variable is a free (independent) variable and (dependent) variable. Test analysis requirement through test normality and variance homogeneity test. Test data normality to determine the normal or absence of the distribution of the research results. While testing techniques of normality through test lilliefors. For data that is said to be normal when price Lcount $<$ Ltable.

Research data collection techniques through observation, interviews, tests and documentation. As for analyzers data by means of testing normality, homogeneity test and hypothesis testing.

\section{RESULTS AND DISCUSSION}

\section{Experimental Classes}

Based on the data from the post-test results in the experimental class of students of VII-6 SMPN 1 Padang Panjang, obtained from the values of the study results that researchers have implemented measures explicit instruction which is tahap1 convey the purpose of learning and Motivate students, Stage 2 demonstrate knowledge or skills, stage 3 guiding training, stage 4 check understanding and give feedback and stage 5 provide training for advanced training. 
The number of students who participated in the learning process of singing Unisono in the experimental class is 25 people. Once known from the Student Learning outcomes (post-test), the highest score achieved by the students in the written post-test is 96, on the post-Test skills 92 . Then the average grade value of the post-test 88.5 whereas in the post-test skills 84.8 .

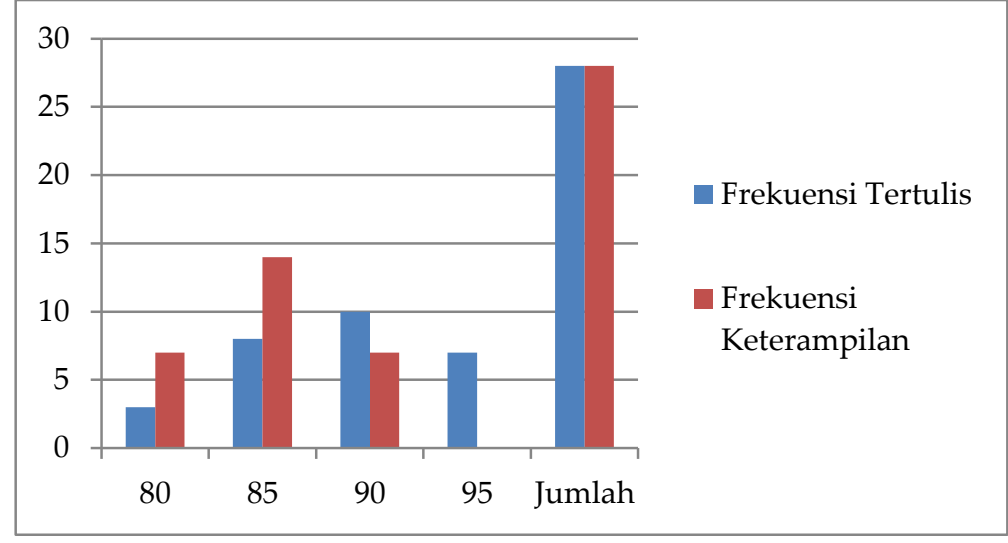

Figure 1. Output frequency distribution Post-Test

\section{Control Class}

The acquisition of post-test result in the control class is VII-4 class of Padang Panjang 1, obtained from the values of the learning that researchers have implemented using conventional media, which is the method of lecture and demonstration. The number of students who participated in the learning process of singing Unisono in the control class is a total of 25 . After the value of the study results (post-test), the highest score achieved by the students in the written post-test is 90, for the post-test skills 85 . And the lowest value for posttest skills is 75 . Hence the average value of grade 84 whereas in the skill of average value of 79.6 .

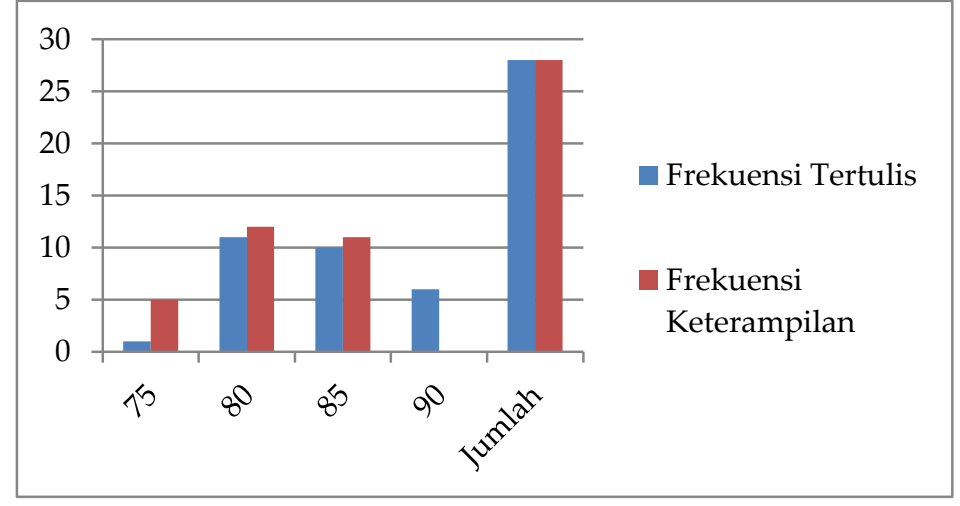

Figure 2. The frequency distribution of Post-Test results

\section{The Influence of Explicit Instruction in Unisono learning}

The effect of implementing explicit instruction learning from the data analysis results obtained the average student value of the experiment class higher when compared with the control class that implemented 
conventional learning methods. This can be seen in the table below.

Table 1. Class value of students from Unisono singing learning

\begin{tabular}{lllll}
\hline & \multicolumn{2}{l}{ Learning outcomes } \\
\cline { 2 - 5 } & \multicolumn{2}{l}{ Experimental classes } & \multicolumn{2}{l}{ Control class } \\
\cline { 2 - 5 } & Written & Skills & Written & Skills \\
\hline Total Students & 28 & & 28 & \\
\hline Highest value & 96 & 92 & 90 & 85 \\
\hline Lowest Value & 80 & 80 & 75 & 75 \\
\hline Average & 88,7 & 85 & 83,7 & 81 \\
\hline Total value & 2485 & 2380 & 2345 & 2270 \\
\hline
\end{tabular}

From the table above, the average value of student learning results in experimentation classes and control classes can be seen that the average written value of the experiment class is 88.7 with the highest value reaching 95 , while the lowest value is 80, with the amount of 2485 value. And at the average skill value in the experimental class is 85 , the highest value reaches 90 and the lowest value of 80 with the amount of 2380 value. While the average written value and skills for the control class, that is 83.7 for written and 81 for skills, and the highest grades on the written and skill control classes are 90 and 85 . While the lowest value is 75 for written and skill, with the amount of written value 2345 while the skill value is 2270 .

Based on the results of the comparisons, the results of learning learners who learn to apply explicit instruction learning model is better than using conventional methods of learning. Because, in the model of learning explicit instruction is made to develop the learning process of learners through procedures knowledge and declaratory knowledge so that all students can understand and fully understand Thoroughly and actively in learning by using a step-by-step study pattern. Because the main objective of implementing explicit instruction learning model is to maximize the use of learners ' learning time, while the positive impact in the learning process is the achievement of maximum learning outcomes and The maximum achievement of academic achievements, skills, increased motivation to learn students and improve their competency and learner.

As for the learning of the control classes using conventional learning methods, teachers are only centered on the lecture and demonstration methods without giving an explanation of the correctly-defined steps in Unisono singing that should be explained to the learners. Thus causing students to become unaware of what they should learn about the Unisono singing, and cause students to become unconcerned about learning, so the goal of Unisono singing learning is not achieved.

\section{CONCLUSIONS}

Based on the research that the influence of Explicit Instruction in Unisono learning in class VII SMPN 1 Padang Panjang, can be concluded: found a very significant difference to the outcomes of learners in class Experiments using the explicit instruction learning model in class VII-6, than in the VII-4 control class using conventional learning methods, it can be seen from the average outcome of written test scores and skills in the class Experimentation amounted to 88.7 for written tests and 85 for skill tests. While in the control class using conventional learning methods, the value of the average result of the class is 83.7 for the written test and the average value of the skill test is 81 . 
And also, from the calculation of $\mathrm{T}$ test count on written test obtained the value of $\mathrm{T}_{\text {count }} 4.05651>$ $\mathrm{T}_{\text {table }}$ 2.0049. As for the skill test acquired the value of $\mathrm{T}_{\text {count }} 3.4420>$ Ttable 2.0049 .

By using the explicit instruction model in Unisono singing learning is very effective to improve the learning outcomes, because the explicit instruction model is made to develop students' learning about the knowledge of procedures and Declarative knowledge so that students can understand and thoroughly know the knowledge thoroughly and actively in a lesson with a pattern step by step. So it is suitable for unisono singing learning, because it applies a pattern step-by-step or gradually in the lesson activities.

Based on the results of the study using the explicit instruction model in cultural arts Studies, the researcher suggested: 1) to the cultural arts teacher is expected to apply a learning explicit instruction model in the material Related or similar, 2) in conducting learning using model explicit instruction, teachers are expected to understand and master the phases or steps in learning, so that the learning activities are effective and efficient, 3) methods Learning explicit instruction is expected to be used as one of the methods of learning to make the learning atmosphere more innovative, 4) to the reader is expected for further research to expand the insight.

\section{REFERENCES}

[1] Ardipal. (2011). Bina Vokalia (Intonasi, Resonansi, dan Artikulasi). Padang: Sukabina Press.
[2] Arends, Richard J. (1997). Classroom Instruction and Management. New York: Mc. Graw Hill.

[3] Asep Jihad dan Abdul Haris. (2012). Evaluasi Pembelajaran. Yogyakarta: Multi Pressindo.

[4] Aqib Zainal. (2013). Model- Model, Media, dan Strategi Pembelajaran Kontekstual (Inovatif). Bandung: Yrama Widya.

[5] Fathurrohman, Muhammad. (2015). Model-Model Pembelajaran Inovatif (Cetakan Pertama). Depok: Ar-Ruzz Media.

[6] Hamzah dan Murdin. (2015). Belajar dengan Pendekatan PAILKEM (Cetakan Keenam). Jakarta: Bumi Aksara.

[7] Istarani. (2011). 58 Model Pembelajaran Inovatif. Medan: Media Persada.

[8] Prasetyo dan Jannah. (2005). Metode Penelitian Kuantitatif: Teori Dan Aplikasi. Jakarta: PT Raja Grafindo Persada.

[9] Rusman. (2010). Model Model Pembelajaran (Edisi Kedua). Jakarta: Kharisma Putra Utama.

[10] Sugiyono. (2014). Metode Penelitian Kuantitatif, Kualitatif dan RED. Bandung: Alfabeta.

[11] Sukmadinata, Nana. (2016). Metode Penelitian Pendidikan. Bandung: PT Remaja Rosdakarya.

[12] Winarno, Ali Zaki, dkk. (2015). Panduan Dasar SPPS. Jakarta: PT Elex Media Komputindo. 